\title{
Inheritance by Contract Institution: Necessity Measures to Design Optimal Legal Construction and Its Regulation
}

\author{
Edward Pilipson \\ Rīga Stradiņš University, Doctoral Studies Programme "Law”, Latvia \\ e.pilipsons@privattiesibas.lv
}

\begin{abstract}
Inheritance by contract institution exists as a complex legal phenomenon. Legal relationships correlating within this institution and outside it do not make it possible to implement harmonisation and to respect balance in regard to the interests of the parties. Based on the given problems, it seems necessary to create a specific understanding of the concept of the person in relation to inheritance by contract. Other measures to construct this institution's legal framework also should be suggested.

Keywords: complex institution, inheritance by contract, leading concept, legal regimes interaction, instability of relationship.

The aim of this article is to designate the indicative list of activities to construct and harmonise the legal structure of the inheritance by contract complex institution.

Up to date, harmonisation of contractual relations in inheritance by contract seems impossible - inheritance by contract complex institution and its leading concept expressed in terms future legacy, future succession, future inheritance in the modern sense did not allow for this kind of relationship to acquire the ability to progress. The complex nature of inheritance by contract in some cases appears as an obstacle, for example, the concept of the future inheritance exists as an impediment for the expression of will of the person to conclude of separate agreements - particular law on inheritance of Israel - the Israeli Succession Law provides the prohibition for testamentary gifts donation (donation agreement mortis causa) without confirmation of this act in testament (Criminal Law of Israeli $)^{1}$.
\end{abstract}

${ }^{1}$ Grazhdanskoje zakonadatelstvo Izrailja (Criminal Law of Israeli). S.-Peterburg: Izd. Juridicheskij centr Press, 2003, 447. (Гражданское законодательство Израиля. ПоА реА. Н. Э. Аившица. С.-Петербург: ИзА. ЮриАический центр Пресс, 2003, 447.) 
The combination of legal regimes providing essential parts for discrete contracts and agreements and one-sided deals can have mixed, unpredicted consequences in particular, the situation cancel of the testament donation agreement mortis causa will be deprived with its legal basis. However, under the law of another state donation agreement mortis causa should be valid, recognised and executed, because will of the testator aims to create not only obligations relations, but simultaneously hereditary, according to the provisions of the norm of the Israeli Succession Law. Instability relationship indicated above also follows from the fact that donation is considered by the legislator as a unilateral transaction - it follows from the provisions of the regulations of the Civil Law of the Republic of Latvia (1937, section 1915) ${ }^{2}$, the Israeli Trust Law (5739-1979) ${ }^{3}$, the Israeli Gift Law (5728-1968)4, the contractual nature of these relationships is discussible (Baikov, 2005).

The main problem of the search applicable to inheritance by contract complex institution law is the lack of a mechanism to link the correct mechanism of the law applicable to inheritance devices and law, applicable to obligations. This is reflected in the contractual succession starting with the formation and determination of this subject matter, ending with consequences - recognition and enforcement of contractual succession tools and devices, both within the field of the national legal system of the state and within margins of discrete states. An additional obstacle to the correct definition of the applicable law is the dichotomy which is expressed in the fact that the collision norms of the Succession and Obligations Law refer the substantive law to the law of the various states simultaneously. Thus, it is possible that the same legal situation will be subject to the application of the law of succession of one state and, accordingly, obligation law of another state is applicable. It seems that this situation is not possible from the point of view of teleological adequacy - legislator, acting within the national legal system allows the linking of institutions separate spheres of legal regulation only in framework of its domestic legal order. Uncontrollable connecting process, exercised with the requirements of the collision norms between succession law discrete institutions and the law of obligations in a situation application of the law of the various states will create unpredictable process to find an applicable law.

The formula which contains connecting factor to attach correct applicable law under the situation of inheritance by contract should contain a comprehensive concept, invested with compound nature, named with term lex loci actus - lex loci solutions. The concept of act should be correlated between the main contract or agreement and possible legal unilateral transaction.

2 The Civil Law of the Republic of Latvia. Section 1915. In order for a gift to be valid, the prospective done or his or her legal representative must accept it.

3 The Israeli Trust Law. Section 2. A trust is created by law, [..] or by instrument of endowment.

${ }^{4}$ The Israeli Gift Law. Section 3. The recipient is presumed to have agreed to the gift, unless he notifies the bestower of its rejection within a reasonable time after he became aware of it. 
It seems necessary to highlight the specific principles of the inheritance by contract. Undoubtedly, the first principle should be the principle of maximum performance of the will of the testator. Traditionally linked with the Inheritance Law, this principle will be the basis for applicable law choice in a situation of execution of inherited obligations ex ante and expost. Reasonably limited with public policy, this principle will ensure the legitimate rights and interests for the heirs and third persons.

For inheritance by contract institution it is important to strengthen the warranty remedies. Legislator of the Republic of Latvia for the realisation of this goal made an important step - amendments of August 4, 2011 in the Civil Procedure Law of Latvia (Amendments on the Civil Procedure Law, 2011) abolished the state fee in cases of entry into force of inheritance contract. The amount of this fee was 15 percent of the genetic evaluation of the inherited masse (Civilprocesa likums, 2011) and its cancellation will play an important role in the contractual succession as a whole.

As a result of the research, the author came to the conclusions set out below.

The traditional and fundamental conflict of laws principles in determining the applicable law on hereditary relationships and testament law in whole is a personal law of the testator, which includes citizenship and domicile. Inheritance proceedings of movables and their accessories are precisely based on these categories. In turn, the inheritance of immovable property is in accordance with the rules of conflict formula lex rei sitae - this principle is based on the law, determined by the location of the property. However, this system does not operate everywhere - German Law uses the principle of unity of the inherited property - for inheritance of movable and immovable property German Law uses the personal law of the testator (Boguslavskij, 2011). The Inheritance Law in situations of inheritance by will as the law applicable to the succession as applicable law establishes the principle of the law, denoted by a place where the will was drawn up (Kurkin, 2008). This situation cannot be applied under the situation of contractual succession. In a situation of inheritance contract, applicable law should be specified otherwise - to inheritance applies binding lex voluntatis parties autonomy in the choice of law, based on the principle of freely expressed will of the parties and its implementation. It is important to mention that in the absence of the choice of law clearly embodied in the text of agreement, the law of the State with which the contract is most closely connected will be used.

On the basis of the mentioned above, it seems necessary to carry out doctrinal and normative allocation of the law order or statute of the inherited obligations with specific legal regulation creation.

It seems that for the determination of the applicable treaty to inheritance rights it would be reasonable to use the categories, named with terms analytical region and regulatory region or, sometimes, normative region. Analytical region is the law (legislation) intended to be used. As a normative region legislation of state, or their combination, which regulates the essential components of the inheritance contract complex institution, should be recognised. 
Because inheritance by contract includes an institution, called with the term future inheritance, respectively hereditatis futurae in Latin, which vested with uncertain legal nature seems necessary to state, that the connecting factor that should regulate the law applicable to inheritance by contract is law prescribed by the place of coincidence of hereditary rights and obligations of the heir and the testator (lex loci coincidentiae).

Doctrinal and practical development of the statute of the inheritance by contract is quite important because testamentary statute of Civil law States covers all the consequences of opening the inheritance. In turn, testamentary statute of Common law countries applies only under problematic issues of the legal status of the heir or heirs, but issues related with categories named with terms administration and probate remains unresolved (Haas, 2004). By simplified combination of the principles and institutions of the Succession Law and the Law of Obligations create a statute of inheritance by contract is not possible - there is an opportunity of the conflict of qualifications.

Moreover, conflict bindings lex personalis and lex rei sitae apply only to denote effects of inheritance, not for the regulation of the law applicable to the legal transaction as a whole (contract, mediating inheritance by contract) and parties' legal interests in it. The law applicable to the contract is governed by the general conflict binding lex voluntatis, which gives the definition of the applicable law entirely according to the will of the parties to contract, often leaves without attention the action of connecting factors lex personalis and lex rei sitae. Limitation executing to conflict binding lex voluntatis action only by public order or, sometimes, public policy of the national state. This situation cannot be acceptable - public order is territorial category.

As of present moment, meaning of the term inheritance by contract priority remains unclear. Legal doctrine - Roland Krauze in Commentaries of Civil Law does not clearly answer this question (Krauze, 1997, 183). Establishing as the basis of priority created by the Inheritance Contract Obligation Law and the Succession Law, giving these fields of the legal regulation the role of organisational law under Henry Hansmann and Reinier Kraakman (Hansmann \& Kraakman, 2000) which leads to the formation of the heirs' property rights, it should be noted that the Obligation Law arises as a form of legal regulation under contract, the law and under testament - this position secured with provisions under section 1672 of the Civil Law of the Republic of Latvia, section 4.5.3. of Dutch Civil Code and in the article 130 of the Civil Code of the Netherlands. Diversity of legal sources mentioned above can generate instability in the content of organisational law - in this case there is an internal conflict (conflict within the regulation) under the meaning of Richard G. Passler (Passler, 1991), Herma Hill Kay (Kay, 1980, 577-617), T. N. Karaseva (Karaseva, 2013, 56-65), T. O. Shilyuk and K. G. Mittelman (Shilyuk \& Mittelman, 2013, 75-82).

Category inheritance by contract priority was accepted and adopted by the Provincial Law of the Baltic Provinces under section 1701. However, in this normative act an important clarification in relation to the law of Kurzeme and Vidzeme was 
made (Provincial Law of the Baltic Provinces, 1928, 190 ${ }^{5}$ - in the light of this clarification inheritance by contract priority really works. The second reason for the introduction of inheritance by contract priority imperative was in the Provincial Law of the Baltic Provinces in a variety of contractual inheritance institutions - their essential components have been enshrined in sections from 2481 till 2524 of the Provincial Law of the Baltic Provinces. With a first cause falling away - the Provincial Law of the Baltic Provinces losses its legal force, under the situation of the Civil Law of the Republic of Latvia category inheritance by contract priority acquired the quality of assessment category or, sometimes, evaluative the concept, evaluative the project created by Ronald Dworkin, which, despite the creation of a certain degree of stability and regulatory strength (Rjasina, 2012, 101) because of the uncertainty and related possibility of unspecified interpretation and concretisation under enforcement process, requires the establishment of criteria for distinguishing institutions (Lukjanenko, 2009, 2, 114) in the case of contractual succession. Otherwise there appears a risk of contradictions and conflicts in the application of the mandatory rules of the Law of Obligations and the Succession Law especially in particular situations of simultaneous conclusion of succession contract and qualification of mutual wills as inheritance contract. The deontic characteristic category should be fixed as priority basis of inheritance by contract priority.

It appears that the text of Article 389 of the Civil Law of the Republic of Latvia all three kinds of inheritance rights may exist simultaneously should be replaced with the phrase succession by law, by will and by contract exists simultaneously. The presence of the word simultaneously and removal of the term may will reflect the current situation in the Succession and Obligation Law in regard to inheritance by contract single and complex situations - institution, named with the term persons entitled to compulsory share has a complex nature and is present not only in the inheritance by law, but also in inheritance under testament and agreement (contract). Additionally, persons entitled to compulsory share will have the right to claim the inheritance, regardless of the base of succession and other agreements, mediating co-respective rights and obligations. A similar situation existed in respect of the institution, named with the term legitimate heirs before amendments (Amendments on the Civil Law of the Republic of Latvia, 2014).

It appears that the basis of the priority inheritance by contract must be combined with the will of the testator and the heir aimed in the process of the creation of hereditary rights and obligations. This provision shall correspond to the position of the will

\footnotetext{
${ }^{5}$ Provincial Law of the Baltic Provinces. Section 1701. An inheritance by contract has a priority in regard to inheritance by testament and, as one, has preference in regard to statutory succession. With respect to Vidzeme all three types of inheritance can exist together on this basis, to one specific part of the whole composition (half, third, quarter, etc.) entitled to testamentary, the other to contractual and third to statutory heir. In Kurzeme, inheritance by contract can exist together with the testamentary as well with statutory succession, but the latter two forms of succession connection are not allowed.
} 
according to provisions of the Civil Law of the Republic of Latvia fixed in section 1437, specialised in relation to inheritance, and to be enshrined in legislation in the Civil Law of the Republic of Latvia in part "Succession Law" in clarified formulation.

The Republic of Latvia is a member of International Institute for the Unification of Private Law of January 1, 2006 (Ärlietu ministrijas dienesta informäcija Nr. 41/66-397, $2006)^{6}$ and, having powers for making proposals for the development perspective of the Private Law (Law of the Republic of Latvia, 2005) ${ }^{7}$ should make proposals on the development and amendments of legal regulation in relation to inheritance by contract as a whole and toward discrete institutions.

In order to establish and justify contractual inheritance conception it seems necessary to enter the category, denoted by the term contractual inheritance - a person in legal intent, this category corresponds with inheritance by contract subject matter fixed in the concept a person in legal contemplation (Wilson v. Estate of WL Kings, 1960). The concept expressed by this term will enable the debtor in the course of fulfillment of the obligations arising from the contract of inheritance or other institution of the contractual succession to settle testamentary obligations before creditors with the best way. Category persona enshrined in the Roman Private Law fixes inter alia the existence of an appropriate expression of the will (Dozdev, 1996, 254). In the situation according to succession by law or by testament heir has a legal opportunity to accept or reject inheritance. In situation of the inheritance contract, the heir may not renounce the inheritance. Due to this circumstance, the legal intention mediated by limited will, must be regulated by contract. The basis of the inheritance by contract is a contract, retreat is not allowed. Moreover, by contractual inheritance in the process of the enforcement ex ante and ex post property rights (Zekoll, 2005, 286) and property (Civil Law of the Republic of Latvia, $1937)^{8}$ can be purchased, the debtor must be insured against possible losses (Godeme, 1948, 107), which include reducing the available assets.

The question of the transfer of ownership rights on the moment of movable property inherited under contractual succession situation remains unsolved. From the point of view of the Law of Succession in the situation according to the Law of Inheritance and Bequest, the actual adoption of the inheritance under peremptory dispositions of

\footnotetext{
${ }^{6}$ Service information of the Ministry of Foreign Affairs No. 41/66-397 on the entry into force of the Statutes. The Ministry of Foreign Affairs informs as of January 1, 2006 in the territory of Latvia 15 March, 1940 Statutes of International Institute for the Unification of Private Law have been enforced.

${ }^{7}$ Law of the Republic of Latvia. International Institute for the Unification of Private Law. Statute. Article 12. (1) Any participating Government, as well as any international institution of an official nature, shall be entitled to set before the Governing Council proposals for the study of questions relating to the unification, harmonisation or coordination of Private Law.

${ }^{8}$ Civil Law of the Republic of Latvia. Section 646. An inheritance contract establishes only a future invitation to inherit and therefore, while the estate-leaver is still alive, grants to a contractual heir only the right to wait for his or her future inheritance, but not an immediately effective right to the present property of the estate-leaver.
} 
the Civil Law of the Republic of Latvia section 691 performed at the time of the debtor specified by the law is in action. Legal doctrine (Briedis, 1939) and practice (Latvijas Republikas Augstākās tiesas Civillietu departamenta ..., 2007, 2014) in relation to inheritance, rightly affirming the principle of continuity in its understanding by Jānis Zariňs (Zariňš, 1935) perpetuate this interpretation. This setting is accepted and valid for inheritance according to the law and will. However, due to the fact that under the contract of inheritance and other contractual instruments inheritance may acquire future inheritance according to mandatory provisions fixed in the Civil Law of the Republic of Latvia section 639, section 8 of the Israeli Succession Law and, accordingly, its fruits fixed under provision of the Civil Law of the Republic of Latvia sections 855 and 856 must be complied with the principle of continuity with regard to things and rights that may not exist at the time of acceptance of the inheritance - these objects may exist as valuable stocks, capital shares in the company, notes, bonds, interest for the use of legitimate interest, other objects, the production and issuance of which shall be agreed with capital society members or with its majority to which the heir due to the period specified in the Civil Law of the Republic of Latvia section 693 and 701 does not apply and inheritance of which are defined by the Commercial Law (2000) ${ }^{9}$ and by the Civil Law of the Republic of Latvia, other codes and normative acts of different countries. Thus, the provisions of Article 980, 991 and 1034 of the Civil Law of the Republic of Latvia (1937), regulating the beginning ${ }^{10}$ and the end of property rights ${ }^{11}$ cannot be used in a situation of inheritance of movable property by concluded or recognised contract.

9 The Commercial Law. Section 87. Taking of Decisions (1) to take a decision, the consent of all the members of the partnership who have the right to take the relevant decision shall be necessary. (2) If a partnership agreement specifies that a decision shall be taken by a majority of votes, then, in case of doubt, a majority shall be determined according to the number of members in the partnership.

The Commercial Law. Section 191. (1) In the case of the death of a shareholder, the shares belonging to him or her shall be inherited by his or her heirs if the articles of association do not specify that the shares devolve to the company. If the articles of association provide for the shares of the deceased shareholder to devolve to the company, then the company has a duty to pay out to the heirs, or in the case specified in Section 416 of the Civil Law - to the state, compensation in conformity with the liquidation quota which the deceased shareholder would have received at the moment of the opening of the succession.

${ }^{10}$ The Civil Law of the Republic of Latvia. Section 980. If items of movable property belonging to various owners are through some process, pursuant to mutual agreement or by chance, joined together, and there is no special arrangement between the participants, then the new property created through such process shall be the joint property of all of them, held in undivided shares, which correspond to the value of each separate, joined property.

The Civil Law of the Republic of Latvia. Section 991. Where property is already in the possession of the acquirer thereof, it shall suffice that there be appropriate notification from the previous owner, in order that the property pass into the ownership of the acquirer.

11 The Civil Law of the Republic of Latvia. Section 1034. Upon the death of an owner, ownership rights devolve to the heirs of the owner. 
Edward Pilipson. Inheritance by contract institution: necessity measures

to design optimal legal construction and its regulation

Developing contractual succession subject matter, it seems necessary to take into account the normative on the necessary diversity arising from the Law of Requisite Variety by William Ross Ashby. Contractual succession is a complex, dynamic and growing entity, according to William Ross Ashby, entropy of a system, concretely: inheritance by contract complex institution in its complicated nature can be increased when included into the system elements act as independent random variables; this extension leads to the loss of control over the whole system (Ashby, 2011, 205-206). In a situation of inheritance contract, this effect can manifest itself in a situation of succession of obligations emanating from the correlated main contract, contracts, agreements and unilateral transactions.

The concept of inheritance by contract should take into account the specific institution, known under the term contracts to leave property by will (Sawyer \& Spero, 2012, 251; Russel Hewitson, 2012). The complex nature of this legal phenomenon requires research with deontic logic methods - as pointed out by Richard Edwards and Nigel Stockwell, provisions of Article 11 of the Inheritance Act 1975 (Inheritance (Provision for Family and Dependants) Act 1975) which the institute is attached to allow the court to modify the effects of the contract if the purchaser has not given or not promised to meet the relevant property at the time of conclusion of the contract (Edwards \& Stockwell, 2005, 160-161).

In the situation of contractual inheritance interest in the analysis of Regulation (EU) No. 650/2012 of the European Parliament and of the Council of July 4, 2012 on jurisdiction, applicable law, recognition and enforcement of decisions and acceptance and enforcement of authentic instruments in matters of succession and on the creation of a European Certificate of Succession (Regulation (EU) No. 650/2012) appears only to analyse issues of the European certificate of inheritance established in this document. Regulation (EU) No. 650/2012 allows to recognise decisions and notarial acts in the area of succession simultaneously providing establishment of the European certificate of inheritance and its granting procedure. In particular, the European certificate of inheritance, drawn up in accordance with Regulation (EU) No. 650/2012 requirements, exists as a legally valid document for the registration of the property and accompanying property rights, transferred by inheritance procedure, the registry of the rights of discrete European Union member state.

However, the legal regulation provided by Regulation (EU) No. 650/2012 is not perfect and sufficient; this normative document overlooks its attention from issues which are attributable to the property regime which have legal ground due to effects of the marriage relationship (Regulation (EU) No. 650/2012, Article 1) ${ }^{12}$, whereas

${ }_{12}$ Regulation (EU) No. 650/2012. Article 1. (2) the following shall be excluded from the scope of this Regulation: (d) questions relating to matrimonial property regimes and property regimes of relationships deemed by the law applicable to such relationships to have comparable effects to marriage; Regulation (EU) No. 650/2012 of the European Parliament and of the Council of 4 July 2012 on jurisdiction, applicable law, recognition and enforcement of decisions and acceptance and enforcement of authentic instruments in matters of succession and on the creation of a European Certificate of Succession. 
according to the inheritance by contract concept include prenuptial agreement or marriage contract mortis causa; simultaneously with the contract of inheritance exists as the basis of the inheritance by contract complex institution. Following the principle of subsidiarity, certificate of inheritance, granted according to Regulation (EU) No. 650/2012 requirements, does not replace the internal documents that can be used for similar purposes under the situation of discrete European Union member state. In this case, the certificate of succession issued in accordance with national legislation and certificate of inheritance absence under Regulation (EU) No. 650/2012 enforcement situation entails limitation and even restriction of hereditary and as a consequence property rights of the heir who was the spouse of the testator - in accordance with the provisions of Article 67 of Regulation (EU) No. 650/2012 notary or other competent authority to issue the certificate of inheritance, should immediately issue a certificate after denoting and establishing of all the elements that require inspection, in accordance with the law applicable to the succession or any other law applicable to specific elements of legal relationship (Regulation (EU) No. 650/2012, Article 67) ${ }^{13}$, assessing individual legal questions issues, regarding the status of the heir in respect to the peremptory norms of the Family Law.

Inheritance by contract appears as an integrated complex of legal regulation. Accordingly, appropriate law denoting provision of adequate protection to the heir as a former spouse of the testator is necessary to search not only in the institutions of the Succession Law, but also in the institutions of the Family Law and in the Law of Obligations. Summarising this statement, it is necessary to affirm that legal regulation of Regulation (EU) No. 650/2012 should be fulfilled with dispositions that will determine the order and procedures of issuing the certificate of inheritance in respect to spouses of the testator and to prevent any disposition of property upon death as well as the use of other freedoms and privileges that may violate the rights of compulsory heirs until their status is not fixed in the certificate of inheritance, provided by the legislation of national state. This measure gives unification nature to Regulation (EU) No. 650/2012 as it is fixed in the Treaty of Maastricht.

${ }^{13}$ Regulation (EU) No. 650/2012. Article 67. (1) the issuing authority shall issue the Certificate without delay in accordance with the procedure laid down in this Chapter when the elements to be certified have been established under the law applicable to the succession or under any other law applicable to specific elements. It shall use the form established in accordance with the advisory procedure referred to in Article 81(2). Regulation (EU) No. 650/2012 of the European Parliament and of the Council of 4 July 2012 on jurisdiction, applicable law, recognition and enforcement of decisions and acceptance and enforcement of authentic instruments in matters of succession and on the creation of a European Certificate of Succession. 
Edward Pilipson. Inheritance by contract institution: necessity measures

to design optimal legal construction and its regulation

\section{Līgumiskās mantošanas institūts: nepieciešamie pasākumi optimālai tiesiskai konstrukcijai un tās regulējumam}

\section{Kopsavilkums}

Līgumiskās mantošanas institūts ir sarežgìta, kompleksa rakstura tiesiskā parādība. Tiesiskās attiecības korelācija šĩ institūta ietvaros un ārpus tās padara neiespējamu saskaṇošanu, līdz ar to arī vienlīdzības ievērošanu attiecībā uz pušu interesēm. Minētās problēmas liecina, ka nepieciešams veicināt izpratni par jēdzienu "persona" attiecībā uz mantošanu pēc līguma. Tiek piedāvāti arī citi pasākumi, lai veidotu šĩ institūta tiesisko regulējumu.

Atslēgvārdi: kompleksa rakstura tiesību institūts, līgumiskā mantošana, tiesību attiecības nestabilitāte, galvenā koncepcija.

\section{References}

1. Amendments on the Civil Law of the Republic of Latvia. Enacted: 08.05.2014. Into force: 01.07.2014. Published: Latvijas Vēstnesis. 98 (5158), 22.05.2014.

2. Amendments on the Civil Procedure Law. Enacted: 04.08.2011. Into force: 01.10.2011. Published: Latvijas Vēstnesis. 132 (4530), 24.08.2011.

3. Ārlietu ministrijas dienesta informācija Nr. 41/66-397. Par Statūtu spēkā stāšanos. Ārlietu ministrija informē, ka 2006. gada 1. janvārī Latvijas Republikā stājas spēkā 1940. gada 15. marta Starptautiskā privāttiesību unifikācijas institūta Statūti (Service information of the Ministry of Foreign Affairs No. 41/66-397 on the entry into force of the Statutes. The Ministry of Foreign Affairs informs as of January 1, 2006 in the territory of Latvia 15 March, 1940 Statutes of International Institute for the Unification of Private Law have been enforced). Enacted: 17.01.2006. Published: Latvijas Vēstnesis. 15 (3383), 25.01.2006.

4. Civilprocesa likums (Civil Procedure Law. Issue No. 15.) Rīga: Tiesu namu aǵentūra, 2011.

5. Regulation (EU) No. 650/2012. 27.7.2012. Official Journal of the European Union. L 201/107.

6. The Civil Law of the Republic of Latvia. Section 646. In: Civil Law of the Republic of Latvia. Enacted: 28.01.1937. Into force: 1.09.1992. Published: Valdības Vēstnesis. 42, 22.02.1937. With amendments.

7. The Civil Law of the Republic of Latvia. Section 980. In: The Civil Law of the Republic of Latvia. Part three. Property Law. Enacted: 28.01.1937. Into force: 01.09.1992. Published: Valdïbas Vëstnesis. 44, 24.02.1937. With amendments.

8. The Civil Law of the Republic of Latvia. Section 991. In: The Civil Law of the Republic of Latvia. Part three. Property Law. Enacted: 28.01.1937. Into force: 01.09.1992. Published: Valdibas Vèstnesis. 44, 24.02.1937. With amendments.

9. The Civil Law of the Republic of Latvia. Section 1034. In: The Civil Law of the Republic of Latvia. Part three. Property Law. Enacted: 28.01.1937. Into force: 01.09.1992. Published: Valdības Vēstnesis. 44, 24.02.1937. With amendments. 
10. The Civil Law of the Republic of Latvia. Section 1915. In: The Civil Law of the Republic of Latvia. Part Four. Obligations Law. Enacted: since 28.01.1937. Into force: since 01.03.1993. Published: Valdības Vēstnesis. 46, 26.02.1937. With amendments.

11. The Commercial Law. Section 87. In: The Commercial Law. Enacted: 13.04.2000. Into force: 01.01.2002. Published: Latvijas Vēstnesis. 158/160 (2069/2071), 04.05.2000.; Ziñotājs. 11, 01.06.2000. With amendments.

12. The Commercial Law. Section 191. In: The Commercial Law. Enacted: 13.04.2000. Into force: 01.01.2002. Published: Latvijas Vēstnesis. 158/160 (2069/2071), 04.05.2000.; Ziṇotājs. 11, 01.06.2000. With amendments.

13. The Israeli Gift Law. Section 3. In: The Israeli Gift Law, 5728-1968. With amendments.

14. The Israeli Trust Law. Section 2. In: The Israeli Trust Law, 5739-1979. With amendments.

15. Ashby, W. R. (with an introduction by Goldstein J.). Variety, Constraint, and the Law of Requisite Variety. E: CO, 2011; 13: 205-206.

16. Baikov, A. M. Obiazatelstvennoie pravo. Otdelnye vidi obiazatelstv (Obligation Law. Diversity of Obligation). Section 2. Riga: BRI, 2005, 144-147. (Байков, А. М. Обязательственное право. Отдельнысе виды обязательств. Часть II. Рига: БРИ, 2005, 144-147.)

17. Boguslavskij, M. M. Mezhdunarodnoie chastnoe pravo: Uchebnik (International Property Law: Course book). 2-e izd., Moskva: Mezhdunarodnye otnosheniia, 1994. (Богуславский, М. М. Международное частное право: Учебник. 2-е изА., перераб. и доп. Москва: МежАународные отношения, 1994.)

18. Briedis, V. Mantojuma pien̦emšana un mantojuma atraidǐ̌̌ana (Acceptance and rejection of inheritance). Rīga, 1939.

19. Dozdev, D. V. Rimskoie chastnoie pravo (Rome Property Law). Moskva: izd. INFRA M-Norma, 1996. (АожАев, А. В. Римское частное право. Москва: ИзА. ИНФРА М-Норма, 1996.)

20. Edwards, R., Stockwell, N. Trusts and Equity. $7^{\text {th }}$ ed. Harlow: Longman, 2005.

21. Godeme, E. Obshchaia teoriia obiazatelstv. (General theory of obligations. Translation from French). Moskva: Iurid. izd-vo MJU SSSR, 1948. (Годэмэ, Е. Общая теория обязательств. Перевод с французского. Пер.: И. Б. Новицкий. Москва: Юридическое изА-во МЮ CCCP, 1948.)

22. Grazhdanskoie zakonadatelstvo Izrailia (Criminal Law of Israeli). S.-Peterburg: Izd. Iuridicheskii centr Press, 2003. (Гражданское законодательство Израиля. ПоА реА. Н. Э. Аившица. С.-Петербург: ИзА. Юридический центр Пресс, 2003.)

23. Haas, U. Der europäische Justizraum in "Erbsachen". In: Gottwald (Hrsg.). Perspektiven der justiziellen Zusammenarbeit in Zivilsachen in der Europäischen Union, Veröffentlichungen der Wissenschaftlichen Vereinigung für Internationales Verfahrensrecht e.V., 2004, 43-112.

24. Hansmann, H., Kraakman, R. The essential role of Organizational Law. The Yale Law Journal. 2000, 110, 388-440.

25. Inheritance (Provision for Family and Dependants) Act 1975. 175 Chapter 63. Into force since November 12, 1975. With amendments.

26. Karaseva, T. N. The problem of eliminating contradictions between the legislation of constituent territories of the Russian Federation and federal legislation. University Proceedings. Volga region. 2013, 3 (27), 56-65.

27. Kay, H. H. The use of comparative impairment to resolve true conflicts: an evaluation of the California experience. California Law Review. 1980, 68 (4), 577-617. 
Edward Pilipson. Inheritance by contract institution: necessity measures

to design optimal legal construction and its regulation

28. Krauze, R. Commentaries of Civil Law. Part Two. Inheritance Law. Riga: Mans Īpašums, 1997.

29. Kurkin, B. A. Mezhdunarodnoe chastnoe pravo: uchebnoe posobie (International Property Law: Study Guide). Moskva: MGIU, 2008. (Куркин, Б. А. Международное частное право: учебное пособие. Москва: МГИУ, 2008.)

30. Latvijas Republikas Augstākās tiesas Civillietu departamenta 2007. gada 9. maija spriedums lietā Nr. SKC-382.

31. Latvijas Republikas Augstākās tiesas Civillietu departamenta 2014. gada 31. marta spriedums lietā Nr. SKC-115/2014.

32. Law of the Republic of Latvia. International Institute for the Unification of Private Law. Statute. Article 12. In: Law of the Republic of Latvia. International Institute for the Unification of Private Law. Statute. Enacted: 15.03.1940. Into force: 01.01.2006. Published: Latvijas Vēstnesis. 191 (3349), 30.11.2005.

33. Lukjanenko, M. F. Usloviia formirovaniia sudeiskogo usmotreniia pri primenenii grazhdansko-pravovykh norm, soderzhashchikh ocenochnye poniatiia (Conditions of formation of judicial discretion in the appplication of the Civil Law, containing evaluation concepts). Rossiiskii iuridicheskii zhurnal. 2009; 5, 114. (Аукьяненко, М. Ф. Условия формирования судейского усмотрения при применении гражАанско-правовых норм, содержащих оценочные понятия. Российский юридический журнал. 2009, 5, 114.)

34. Passler, R. G. Comparative impairment: Louisiana's new methodology for resolving conflicts of law. Louisiana Law Review. 1991, 52 (2), 409-435.

35. Provincial Law of the Baltic Provinces. Section 1701. Vietējo Civillikumu Kopojums. Rìga, 1928.

36. Rjasina, A. S. Rol pravoprimenitelia v kontekste upotrebleniia ocenochnykh kategorii (The role of law enforcers in the context of the use of evaluation categories). Vestnik PAGS. 2012, 101. (Рясина, А. С. Роль правоприменителя в контексте употребления оценочных категорий. Вестник ПАГС. 2012, 101.)

37. Russel Hewitson. Property Law Statutes: 2011-2012. $1^{\text {st }}$ ed. New York: Routledge, 2012.

38. Sawyer, C., Spero, M. Succession, Wills and Probate. $3^{\text {rd }}$ ed. Abington: Routledge, 2015.

39. Shilyuk, T. O., Mittelman, K. G. On the issues of conflict of laws of the constituent subjects of the Russian Federation on education. Lex Russica. 2013, 1, 75-82.

40. Wilson v. Estate of WL Kings. 131 Ind. App. 412 (1960). 170 N.E.2d 63.

41. Zariňš, J. Mantojuma dalǐšana tiesas ceḷā (Heritage division with the help of court). Rìga, 1935.

42. Zekoll, J., Reimann, M. Introduction to German Law. $2^{\text {nd }}$ ed. Wolters Kluwer, 2005, 286. 